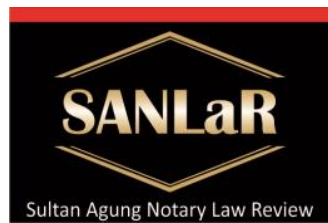

Volume 3 No. 1, March 2021
Sultan Aqung

Notary Law Review

Legal Certainty of Application...( Ani Muhammad Syuaib)

\title{
Legal Certainty of Application of Electronic Archives in Keeping Minutes of Notary Deed as Authentic Evidence
}

\author{
Andi Muhammad Syuaib ${ }^{*}$, Amin Purnawan ${ }^{* *}$ and Akhmad Khisni ${ }^{* * *}$ )
}

*) Student of Master of Notary Law, Faculty of Law, Universitas Islam Sultan Agung (UNISSULA) Semarang E-mail: anisyuaib94@gmail.com
$\left.{ }^{* *}\right)$ Lecturer of Master of Notary Law, Faculty of Law, Universitas Islam Sultan Agung (UNISSULA) Semarang
${ }^{* * *}$ Lecturer of Master of Notary Law, Faculty of Law, Universitas Islam Sultan Agung (UNISSULA) Semarang

\begin{abstract}
This study aims to: to determine whether the application of the use of electronic archives for notarial deeds can provide legal certainty. The approach method in this research is normative law, the data source is obtained from literature and the legal materials used are primary, secondary and tertiary legal materials which are then analyzed by means of qualitative analysis. Based on the results of data analysis, it can be concluded thatthe use of electronic archives as a minimum of a notary deed has not yet obtained a strong legal basis, so it has not guaranteed legal certainty. Legal certainty can be achieved, if there are no conflicting provisions between one law and another. The legal substance in the use of electronic archives as a minimum of notary deeds has not been fully accommodated in the UUJN with the obligation to read the deed in the presence of witnesses and failure to fulfill this requirement will result in legal sanctions for the notary. The ITE Law, which is a legal basis for notaries, also does not provide an opportunity for electronic deeds by providing restrictions on notary deeds that are not included in electronic documents / information, so that they cannot be used as valid evidence. The incompatibility between UUJN and the ITE Law, and the ITE Law with the UUPT regarding the authority of notaries in the use of electronic records is clearly a separate obstacle for notaries. The current legal substance has not been able to facilitate the various interests of the community. Because the substance of the law has not accommodated the interests of the community, the existing legal regulations are not able to adapt to new things that are happening in the community, resulting in no guarantee of legal certainty. The substance of the law is not yet futuristic, because the regulation of the notary's authority cannot anticipate events that may arise in the future, namely the demands of the public so that notaries are able to make deeds electronically. The legal structure that was built has not been able to encourage the implementation of electronic services by notaries properly and optimally. In addition, the legal culture of the community tends to believe more in using conventional facilities than with technology.
\end{abstract}

Keywords: Legal Certainty; Electronic Archives; Minuta notary deed; Legislation. 


\section{Introduction}

Notary is a public official who has the mandate and authority of the state in the form of duties, obligations and authorities in providing services to the general public in the civil sector. The existence of a notary is contained in the Civil Code, especially in Book Four on Evidence and Expiration. Then regarding the main evidence in civil law is written evidence, while the strongest written evidence is in the form of an authentic deed. Notary deed is a perfect, strongest and full tool of proof so that in addition to guaranteeing legal certainty, notarial deeds can also avoid disputes. Putting an act, agreement, stipulation in the form of a notary deed is considered better than writing it in a letter under hand, even though it is signed on a stamp duty, which was also confirmed by the signatures of the witnesses.

Not only do notaries have authority but also office administration obligations like a company. Notary office administration can be defined as activities of a written nature (administrative activities), such as writing a list of deeds, a list of letters under legalized hands, a list of letters underBefore giving credit, the bank ensures that all juridical aspects related to credit have been resolved and are believed to provide adequate protection for the bank, namely by means of credit that must be written in writing, either deed under the hand with sufficient duty stamp or notary deed which is also contained in the State Gazette Republic of Indonesiahand booked, Klapper's alphabetical list, protest list book; a wills register, and a limited liability company register book. The notary's administrative activities are inseparable from the notary's managerial expertise in carrying out filing procedures. The notary office filing is also part of the notary's administrative activities. The procedure for keeping the original or original deed and its documents is also the responsibility of the notary in order to maintain and safeguard the state archives properly and seriously.

The large number of recording activities by the notary raises its own problems in terms of storage. The storage period for these archives if they comply with the regulations regarding company documents is a minimum of 30 years. This period of time is not short and along the way there is often a risk of damage or even loss. The Regional Supervisory Council is unable to store thousands of notary protocols that are over 25 years old in the Regional Supervisory Council office because the Supervisory Council itself does not have an office to store these documents, so the notary protocols are kept in the notary office concerned. This means that the provisions of Article 63 paragraph (5) of Act No. 2 of 2014 cannot be implemented properly.

Act No. 11 of 2008 concerning Electronic Information and Transactions, hereinafter abbreviated as (ITE Law), regulates the mechanism for the use of electronic signatures, where everyone can use an electronic signature (e-signature) which is supported by an electronic certification service provider. Basically, an electronic signature and its electronic certification system are held to clarify the identity of legal subjects and 
protect the security and authenticity of electronic information communicated through electronic systems. ${ }^{1}$.

It cannot be denied that in everyday life and transactions, notaries have been recognized and valued as parties worthy of trust by the public. Notary is an official or legal professional who is sworn to act in accordance with the law properly, so it can be said that a notary is indispensable to ensure the legality of an act or to prevent any illegal act.

By looking at the provisions above, the writer is of the opinion that the transfer of protocols in electronic form cannot be juxtaposed with authentic evidence, considering that the deed is also part of the notary protocol. Proof of authenticity of these documents must be written on paper and made by the authorized official. Documents in electronic form are still ordinary evidence, meaning that the power of proof on electronic documents cannot be said to be the same or equivalent to the power of proof on an authentic deed. So that documents in electronic form cannot stand alone as valid evidence in court, unless supported by other evidence, such as testimony from witnesses or expert witnesses, even though the documents in electronic form are the results of print out, output.

\section{Research methods}

The research method used is normative through a statutory approach with documentary study techniques to obtain primary, secondary and tertiary data and then analyzed with descriptive analytical depiction. ${ }^{2}$

\section{Results and Discussion}

\subsection{Why hasn't the use of electronic archives been determined in the storage of Notary Deed Minutes?}

Based on Article 15 paragraph (1), Article 16 paragraph (1) letter b, Article 58, Article 59 and Article 63 of the UUJN that notaries are responsible for keeping notaries' deeds and protocols during their tenure and will be continued by the next notary who replaces them. The work of notaries is still very much dependent on paper as a medium, so it takes a large space and expensive maintenance to secure these files. In connection with this problem, the application of information technology products can be a solution option for solving these storage problems. Article 68 paragraph (1) of the Archives Law has stipulated that "Creators of archives and / or archival institutions can create archives in various forms and / or transfer media including electronic media and / or other media", but the notary has not implemented it. In the Amendment UUJN, there is no regulation regarding the electronic storage of notary protocols. Only the elucidation of Article 15 paragraph (3) states the possibility of a notary to certify transactions conducted electronically (cyber notary). The government, through the

\footnotetext{
${ }^{1}$ Mohamat Riza Kuswanto. Urgency for Notary Protocol Storage in Electronic Form Journal of the Repertorium Volume IV No. July 2 - December 2017

${ }^{2}$ H. Halim HS \& Erlies S. Nurbani. (2013). application of legal theory in thesis and dissertation research. Jakarta: Raja Grafindo Persada. Thing. 17-18
} 
Ministry of Law and Human Rights, began to provide legal services online with the issuance of Regulation of the Minister of Law and Human Rights Number 4, 5, 6 of 2014. The absence of regulations governing electronic storage of notary protocols in UUJN has created a norm vacuum. Based on Plato's view that a good country is a country based on the existence of a good (law) regulation, ${ }^{3} \mathrm{Good}$ statutory rules are regulations that provide legal certainty so as to create a safe and peaceful atmosphere in society. Regarding the theory put forward by Van Apeldoorn regarding legal certainty which means that:

1. Legal certainty is something that can be determined from law, related to concrete things.

2. Legal certainty is legal security. One of the ways to achieve legal certainty is if there are clear and consistent rules. The laws and regulations referred to in this discussion are the implementing regulations of the UUJN relating to the electronic storage of notary protocols.

Legal remedies that can be taken to realize notary protocol storage in electronic form, in the absence of laws and regulations that explicitly regulate the electronic storage of notary protocols in UUJN, only in the Elucidation of Article 15 paragraph (3) which states the possibility of notaries to certify transactions conducted electronically (cyber notary) as well as the restriction provided by the ITE Law in Article 5 paragraph (4) that the electronic document does not meet the document authenticity requirements as stipulated in Article 1 number 7 of the Amendment LawJN and Article 1868 of the Civil Code, makes the transfer of notary protocol storage can only function electronically as a back up, not as a binding force copy. Therefore it is necessary to revise the relevant laws so that the electronic storage of deeds carried out by an electronic system whose operation is in accordance with the prevailing laws and regulations has the same evidentiary power as the original.

Based on the two types of deeds made by notaries, for now it is not possible to apply information technology in making electronic notary deeds. Especially in making deeds of relaas. Here, the presence of a notary in front of the parties is a must so that an official report can be made containing a description of the notary that has been seen and witnessed by the notary himself at the request of the parties. ${ }^{4}$.

The problem that then arises in making authentic deeds electronically is related to the obligations that a notary must carry out on the deed he makes, as regulated in Article 16 paragraph (1) UUJN, in particular Article 16 paragraph (1) UUJN letters c, and m, which reads in full: 1 . Attaching letters and documents as well as fingerprints of faces to the Minuta Deed; 2 . Read out the Deed in front of an audience in the presence of at least 2 (two) witnesses, or 4 (four) special witnesses for the making of the will under hand, and signed on the spot by the tappers, witnesses and notary public.

\footnotetext{
${ }^{3}$ Makarim, Edmon, 2013, Notary \& Electronic Transaction of Legal Studies on Cybernotary or Electronic Notary, Raja Grafindo Persada, Jakarta.

${ }^{4}$ Anshor i, Abdul Ghofur, 2010, Indonesian Notary Institute for Legal and Ethical Perspectives, UII Press, Yogyakarta.
} 
Based on the two types of deeds made by notaries, for now it is not possible to apply information technology in making electronic notary deeds. Especially in making deeds of relaas. Here, the presence of a notary in front of the parties is a must so that an official report can be made containing a description of the notary which the notary has seen and witnessed at the request of the parties.

Furthermore, when referring to the provisions of Article 5 paragraph (4) letters $a$ and $b$ of the ITE Law, it is known that documents made in the form of notary deeds are not included in electronic information and / or electronic documents. So that notarial deeds made electronically do not have legal force as valid evidence according to the provisions of the ITE Law. With the limitation on the meaning of electronic information / electronic documents as stipulated in Article 5 paragraph (4) letters a and b, authentic deeds made electronically by notaries are deemed unable to be valid evidence. So, the authenticity of the deed made by the notary in this case is not fulfilled. ${ }^{5}$

\section{Closing}

The use of electronic archives as a minimum of a notary deed has not yet obtained a strong legal basis, so it has not guaranteed legal certainty. Legal certainty can be achieved, if there are no conflicting provisions between one law and another. The opportunity for a notary to make deeds electronically cannot be applied because there is no synchronization (contrary) to UUJN and UU ITE. Article 16 paragraph (1) letter $\mathrm{m}$ UUJN obliges a notary to read the deed in front of the audience in the presence of at least 2 (two) witnesses. Whereas in Article 5 paragraph (4) of the ITE Law which provides limitations by excluding notary deeds, it is not included in the category of electronic information / documents. The legal substance in the use of electronic archives as a minimum of notary deeds has not been fully accommodated in the UUJN with the obligation to read the deed in the presence of witnesses and failure to fulfill this requirement will result in legal sanctions for the notary. The ITE Law, which is a legal basis for notaries, also does not provide an opportunity for electronic deeds by providing restrictions on notary deeds that are not included in electronic documents / information, so that they cannot be used as valid evidence under the ITE Law. So that the opportunity to use electronic archives as a minimum open notary deed through electronic media as regulated in the Company Law cannot be implemented yet, because the legal substance that regulates the authority of notaries in making deeds electronically is accommodated and there is still synchronization with other laws. Thus, here the law has not yet achieved its essential objective, namely to provide legal benefits to the community and to guarantee legal certainty for legal events that develop in society.

\section{References}

Journals:

${ }^{5}$ Emma Nurita. Cybernotary Early Understanding and Concept Thought. Jakarta: Refika Aditama, 2014. 
[1] Lubbe, JCA Vam Der and Nauta, 1992. "Culture and Expert Systems ", Peircean semiotics. Int.Information and Documentation Forum Journal. Vol. 17 No. 3

[2] Rahadi Wasi Bintoro. 2011. "Application of Law in Electronic Transaction Dispute Resolution in General Courts".Journal Legal Dynamics. Vol. 20 No. 12

[3] Triyanti. 2015. "Evidence Power of Electronic Documents as Substitute Minutes of Notary Deed. Postgraduate".Repertorium Journal. Volume II No. 2

Books:

[1] Edmon Makarim. (2014). Notary and Electronic Transactions, Legal Studies About Cybernotary or Electronic Notary. Jakarta: Sinar Grafika

[2] Emma, 2012, Cyber Notary Early Understanding in the Concept of Thought. Bandung: PT. Refika Adi Tama

[3] H. Halim HS \& Erlies S. Nurbani. (2013). Application Of Legal Theory In Thesis And Dissertation Research. Jakarta: Raja Grafindo Persada.

[4] Kie, Tan Thong. (2013). Notarial Studies \& All-round Notary Practices. Jakarta: PT. Icht iar Baru Van Hoeve

[5] Notodisoerjo, R. Soegondo. (1993. Notariat Law in Indonesia An Explanation. Jakarta: Rajawali Pers

[6] Sugiarto, Agus, Teguh Wahyono. (2014). Electronic Records Management. Yogyakarta: Gava Media

Internet:

Rio Admiral. www.kearsipanonline.com Keeping the Notary Records for Who's Responsibilities, accessed at 20.78 WIB on December 8, 2020

Regulations:

[1] Code of Civil law (Burgerl i jk Wetboek, Staat sblad 1847-23), translated by R. Soesilo and Pramudji R, Rhedbook Publisher, Jakarta

[2] Act No. 30 of 2004 concerning Notary Position (State Gazette of the Republic of Indonesia of 2004 Number 117, Supplement to the State Gazette of the Republic of Indonesia Number 4432).

[3] Act No. 11 of 2008 concerning Electronic Information and Transactions (State Gazette of the Republic of Indonesia of 2008 Number 58, Supplement to the State Gazette of the Republic of Indonesia Number 4843).

[4] Act No. 43 of 2009 concerning Kear cipa (State Gazette of the Republic of Indonesia of 2009 Number 152, Supplement to the State Gazette of the Republic of Indonesia Number 5071). 
[5] Act No. 2 of 2014 concerning Amendments to Act No. 30 of 2004 concerning the Position of Notary (State Gazette of the Republic of Indonesia of 2004 Number 3, Supplement to the State Gazette of the Republic of Indonesia Number 5491). 